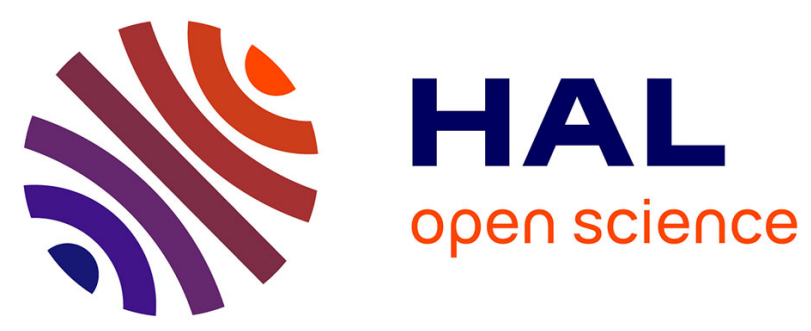

\title{
Evaluation of the culture-enhanced Xpert MTB/RIF assay for the diagnosis of smear-negative tuberculosis
}

Latifa Noussair, Frédéric Bert, Véronique Leflon-Guibout, Roselyne Métivier, Chantal Chauvet, Catherine Napol, Marie-Hélène Nicolas-Chanoine

\section{To cite this version:}

Latifa Noussair, Frédéric Bert, Véronique Leflon-Guibout, Roselyne Métivier, Chantal Chauvet, et al.. Evaluation of the culture-enhanced Xpert MTB/RIF assay for the diagnosis of smear-negative tuberculosis. Médecine et Maladies Infectieuses, 2019, 49, pp.467 - 470. 10.1016/j.medmal.2018.11.004 . hal-03488178

\section{HAL Id: hal-03488178 \\ https://hal.science/hal-03488178}

Submitted on 20 Dec 2021

HAL is a multi-disciplinary open access archive for the deposit and dissemination of scientific research documents, whether they are published or not. The documents may come from teaching and research institutions in France or abroad, or from public or private research centers.
L'archive ouverte pluridisciplinaire HAL, est destinée au dépôt et à la diffusion de documents scientifiques de niveau recherche, publiés ou non, émanant des établissements d'enseignement et de recherche français ou étrangers, des laboratoires publics ou privés.

\section{(ㄷ)(1) $\$$}

Distributed under a Creative Commons Attribution - NonCommerciall 4.0 International 
Evaluation of the culture-enhanced Xpert MTB/RIF assay for the diagnosis of smearnegative tuberculosis

\section{Évaluation du test Xpert MTB/RIF sur une pré-culture pour le diagnostic de la tuberculose à frottis négatif}

Latifa Noussair $^{1 * \$}$, Frédéric Bert $^{1 \$}$, Véronique Leflon-Guibout $^{1}$, Roselyne Métivier ${ }^{1}$, Chantal Chauvet $^{1}$, Catherine Napol ${ }^{1}$, Marie-Hélène Nicolas-Chanoine ${ }^{1,2,3}$

${ }^{1}$ AP-HP, Hôpital Beaujon, Service de Microbiologie, Clichy, France

${ }^{2}$ Faculté de Médecine D. Diderot, Université Paris VII, Paris, France

${ }^{3}$ INSERM U 773, Centre de Recherche Biomédicale Bichat-Beaujon, CRB3, Paris, France

(*) Current address: 2IC, UMR1173, Inserm, université Versailles St Quentin, Versailles et APHP, Hôpital Raymond Poincaré, Service de microbiologie, Garches, France

(\$) Corresponding authors: Dr L. Noussair (latifa.noussair@aphp.fr) and Dr F. Bert (frederic.bert@aphp.fr)

Keywords: tuberculosis, GeneXpert, molecular diagnosis, rifampicin resistance

Mots clés : tuberculose, GeneXpert, diagnostic moléculaire, résistance à la rifampicine

\section{Contribution of authors}

MHNC and LN designed the study protocol.

$\mathrm{RM}, \mathrm{CC}, \mathrm{CN}$, and $\mathrm{LN}$ performed the experiments.

$L N, F B, V L G$, and MHNC wrote the article. 


\section{Abstract}

Objectives. To evaluate a new tool for the early diagnosis of tuberculosis.

Methods. A total of 374 smear-negative clinical specimens from patients presenting with suspected tuberculosis were evaluated using a new procedure consisting of a preliminary step of culture in broth bottles followed by the detection of Mycobacterium tuberculosis complex (Mtb) and rifampicin resistance by the Xpert MTB/RIF assay (XMTB-RIF).

Results. A total of $30 \mathrm{Mtb}$ strains were isolated, all susceptible to rifampicin. When broth cultures were subjected to XMTB-RIF analysis after 15 days of incubation, sensitivity, specificity, PPV, and NPV were each $100 \%$ when compared with liquid culture.

Conclusion. The XMTB-RIF assay used in 15-day broth cultures may provide a final culture result for smear-negative specimens. This process, combined with clinical signs, may contribute to rapidly diagnosing tuberculosis and also to the early re-evaluation of empirical antituberculosis treatment. 


\section{Résumé}

Objectifs. Évaluer un nouvel outil pour le diagnostic précoce de la tuberculose.

Méthodes. 374 échantillons cliniques à frottis négatif issus de patients suspects de tuberculose ont été analysés avec une nouvelle procédure : culture en bouillon suivie de la détection du complexe tuberculosis (Mtb) et de la résistance à la rifampicine par test Xpert MTB/RIF (XMTB-RIF).

Résultats. 30 souches de Mtb sensibles à la rifampicine ont été isolées. Lorsque les cultures en bouillon ont été soumises à une analyse XMTB-RIF après 15 jours d'incubation, la sensibilité, spécificité, VPP et VPN étaient toutes de $100 \%$ comparativement à la culture liquide.

Conclusion. Le test XMTB-RIF appliqué à des cultures en bouillon incubé 15 jours peut fournir un résultat définitif de la culture pour les échantillons à frottis négatif. Cette procédure peut aider au diagnostic précoce de la tuberculose et contribuer à la réévaluation précoce de la thérapie antituberculeuse empirique. 


\section{Introduction}

Tuberculosis (TB) remains one of the major public health problems in developing and industrialized countries [1]. The worldwide control of the disease has been hampered by diagnostic difficulties relating to poor sensitivity of smear microscopy and slow growth of mycobacteria. Recently, the ability of nucleic acid amplification tests to rapidly and accurately detect Mycobacterium tuberculosis complex (Mtb) and its resistance to the firstline drug rifampicin in clinical specimens has offered significant advantages for the management and control of TB [2].

However, the major drawback of these molecular assays is still their limited ability to provide an accurate result when testing smear-negative specimens. Whilst the Xpert MTB/RIF (XMTB-RIF) provides 96\%-100\% sensitivity on smear-positive respiratory and non-respiratory specimens [3-12], this is reduced to only $57 \%-83 \%$ for smear-negative respiratory specimens and to $37 \%-75 \%$ for non-respiratory specimens [3-14]. Its negative predictive value (NPV) to rule out the diagnosis of tuberculosis on smear-negative specimens is therefore far from optimal.

We previously developed a culture-enhanced PCR test consisting in a preliminary step of broth culture followed by the molecular detection of $M t b[15]$. This procedure was shown to be highly sensitive and specific for the detection of $M t b$ in paucibacillary specimens. On this occasion we set out to evaluate the performance of the XMTB-RIF directly on liquid cultures of 374 respiratory and non-respiratory specimens from patients presenting with a suspicion of TB, after 5,10 , or 15 days of incubation. We were thus able to confirm the true negativity of smear-negative specimens after 15 days of incubation as opposed to eight weeks of conventional microbiological incubation. The antituberculosis treatment could therefore be re-evaluated sooner alongside clinical sign and symptom evaluation. 


\section{Materials and methods}

Three hundred and seventy-four smear-negative specimens (respiratory and nonrespiratory) (Table 1) were obtained from 320 patients presenting with a suspicion of TB. Consecutive specimens were considered as a single specimen with the sediments obtained from the three bottles pooled to perform a single XMTB-RIF test. Respiratory and nonrespiratory specimens were analyzed as previously described [15]. Liquid (BactT/Alert, BioMérieux) and solid (Lowenstein-Jensen, BioMérieux) cultures were monitored for up to eight weeks at $37^{\circ} \mathrm{C}$. A $2.5 \mathrm{ml}$ aliquot, after centrifugation, was subjected to XMTB-RIF assay according to the manufacturer's recommendations. A total of 177 smear-negative specimens were tested after a 5-day broth culture (December 2010 - June 2011), 89 smear-negative specimens were tested after a 10-day broth culture (July 2011 - October 2011), and 108 smear-negative specimens were tested after a 15-day broth culture (November 2011 February 2012). Isolated Mtb strains were tested for rifampicin (RMP) resistance by conventional drug susceptibility testing. A positive culture of $M t b$ in liquid medium was considered the gold standard for calculating the clinical values of the XMTB-RIF assay.

\section{Results}

Three hundred and seventy-four smear-negative specimens obtained from 320 patients, including 165 respiratory specimens and 209 non-respiratory specimens, were tested using the culture-enhanced XMTB-RIF procedure. Respiratory specimens included sputum and gastric aspirates $(n=86)$, bronchial washings $(n=44)$, and bronchoalveolar lavage $(n=35)$. Nonrespiratory specimens included lymph nodes $(n=46)$, vertebral biopsies $(n=31)$, peritoneal fluid ( $n=31$ ), pleural fluid ( $n=29)$, gastrointestinal and liver biopsies $(n=23)$, cerebrospinal 
fluid ( $n=11)$, cerebral biopsies $(n=8)$, cutaneous biopsies $(n=7)$, and other specimens $(n=23)$. Overall, 30 out of 374 specimens were liquid culture-positive for Mtb. Twenty-seven out of 374 specimens were solid culture-positive for Mtb. The positivity rates according to the specimen type are detailed in Table 1 . The mean time to positive detection by the BacT/Alert instrument was 25 days (range 12-43).

From December 2010 to June 2011, 177 smear-negative specimens obtained from 163 patients were tested. Fourteen (7.9\%) specimens were culture-positive. The XMTB-RIF assay detected Mtb on Day 5 in 9 of 14 culture-positive specimens (64.3\%) (Table 1). The remaining 163 culture-negative specimens were also XMTB-RIF-negative. Sensitivity, specificity, positive predictive value (PPV), and NPV were 64\%, 100\%, 100\%, and 97\% respectively, as compared with liquid culture (Table 2).

From July 2011 to October 2011, 89 smear-negative specimens obtained from 65 patients were tested. Seven (7.9\%) specimens were positive in culture (Table 1). The XMTB-RIF assay was positive in five of seven $(71.4 \%)$ culture-positive specimens. All remaining specimens, negative in liquid culture, were also negative with the XMTB-RIF assay. Sensitivity, specificity, PPV, and NPV were $71.4 \%, 100 \%, 100 \%$, and $97.6 \%$ respectively, as compared with liquid culture (Table 2).

From November 2011 to February 2012, 108 smear-negative specimens obtained from 92 patients were tested. Broth culture was positive in 9 of 108 specimens (8.3\%). The XMTB-RIF assay was positive on all culture-positive specimens on Day 15 (Table 1). All culture-negative specimens ( $n=99$ ) were XMTB-RIF-negative. Sensitivity, specificity, PPV, and NPV were each $100 \%$ when compared with liquid culture (Table2).

The $30 \mathrm{Mtb}$ isolates were found susceptible to RMP by conventional biochemical drug susceptibility assays. The same result was observed with the XMTB-RIF assay. 


\section{Discussion}

The sensitivity and specificity of nucleic acid amplification tests are usually evaluated against conventional bacteriological culture as the gold standard diagnosis. These tests, including the recently developed XMTB-RIF assay, have shown high specificity and high PPV but highly variable sensitivity and NPV, especially for smear-negative specimens [3, 7, 9-12].

The XMTB-RIF assay failed to detect Mtb in 5 of the 14 culture-positive specimens on Day 5 and in 2 of the 7 culture-positive specimens on Day 10. A 15-day incubation period was required to reach perfect concordance between culture results and XMTB-RIF results. Thus, the efficacy of the culture-enhanced XMTB-RIF procedure to predict final broth culture result was similar to that previously reported with the GTMD assay [15].

The early diagnosis of smear-negative tuberculosis cases, particularly extra-pulmonary tuberculosis, remains challenging because patients often present with atypical clinical signs and symptoms. The length of time required to obtain microbiological confirmation by culture may result in delays in appropriate therapy initiation or in unnecessarily prolonged empirical treatment. In our study, negative XMTB-RIF assay on Day 15 led to ruling out with confidence the presence of $M t b$ in tested specimens several weeks before final broth culture result availability. Alongside a high level of clinical judgement, this procedure may be used for the early reevaluation of antituberculosis treatment. 


\section{References}

[1] WHO. Global tuberculosis control: a short update to the 2009 report. World health organization, Geneva, Switzerland 2010.

[2] Centers for Disease Control and Prevention. Updated guidelines for the use of nucleic acid amplification tests in the diagnosis of tuberculosis. MMWR Morb Mortal Wkly Rep 2009; 58:7-10.

[3] Armand S, Vanhuls P, Delcroix G, Courcol R, Lemaître N. Comparison of the Xpert MTB/RIF test with an IS6110-TaqMan real-time PCR assay for direct detection of Mycobacterium tuberculosis in respiratory and nonrespiratory specimens. J Clin Microbiol 2011; 49:1172-1176.

[4] Boehme CC, Nabeta P, Hillemann D, Nicol MP, Shenai S, Krapp F, Allen J, Tahirli R, Blakemore R, Rustomjee R, Milovic A, Jones M, O’Brien SM, Persing DH, RueschGerdes S, Gotuzzo E, Rodrigues C, Alland D, Perkins MD. Rapid molecular detection of tuberculosis and rifampicin resistance. N Engl J Med 2010; 363:1005-1015.

[5] Bowles EC, Freyée B, Van Ingen J, Mulder B, Boeree JM, Van Soolingen D. Xpert MTB/RIF , a novel automated polymerase chain reaction-based tool for the diagnosis of tuberculosis. Int J Tuberc Lung Dis 2011; 15:988-989.

[6] Helb D, Jones M, Story E, Boehme C, Wallace E, Ho K, Kop J, Owens MR, Rodgers R, Banada P, Safi H, Blakemore R, Ngoc Lan NT, Jones-López EC, Levi M, Burday M, Ayakaka I, Mugerwa RD, McMillan B, Winn-Deen E, Christel L, Dailey P, Perkins MD, Persing DH, Alland D. Rapid detection of Mycobacterium tuberculosis and rifampicin resistance by use of on-demand, near-patient technology. J. Clin Microbiol 2010; 48:229-237. 
[7] Miller MB, Popowitch EB, Backlung MG, Ager EPC. Performance of Xpert MTB/RIF RUO assay and IS6110 real-time PCR for Mycobacterium tuberculosis detection in clinical samples. J Clin Microbiol 2011; 49:3458-3462.

[8] Nicol MP, Workman L, Isaacs I, Munro J, Black F, Eley B, Boehme CC, Zemanay W, Zar HJ. Accuracy of the Xpert MTB/RIF test for the diagnosis of pulmonary tuberculosis in children admitted to hospital in Cape Town, South Africa: a descriptive study. Lancet Infect Dis 2011; 11:819-824.

[9] Rachow A, Zumla A, Heinrich N, Rojas-Ponce G, Mtafya B, Reither K, Ntinginya EN, O'Grady J, Huggett J, Dheda K, Boehme C, Perkins M, Saathoff E, Hoelscher M. Rapid and accurate detection of Mycobacterium tuberculosis in sputum samples by Cepheid XMTB-RIF- A clinical validation study. PLoS One 2011; 6:e20458.

[10] Tortoli E, Russo C, Piersimoni C, Mazzola E, Dal Monte P, Pascarella MBorroni E, Mondo A, F. Piana, Scarparo C, Coltella L, Lombardi G, Cirillo MD. Clinical validation of Xpert MTB/RIF for the diagnosis of extrapulmonary tuberculosis. Eur R espir J 2012; Aug; 40(2):442-7.

[11] Vadwai V, Boehme C, Nabeta P, Shetty A, Alland D, Rodrigues C. Xpert MTB/RIF: a new pillar in diagnosis of extrapulmonary tuberculosis? J. Clin. Microbiol 2011; 49:25402545.

[12] Zeka A. Tasbakan NS, Cavusoglu C. Evaluation of the GeneXMTB-RIF for rapid diagnosis of tuberculosis and detection of rifampicin resistance in pulmonary and extrapulmonary specimens. J Clin Microbiol 2011; 49:4138-4141.

[13] Hillemann D, Rüsch-Gerdes S, Boehme C, Richter E. Rapid molecular detection of extrapulmonary tuberculosis by the automated GeneXpert MTB/RIF system. J ClinMicrobiol 2011; 49:1202-1205. 
[14] Moure R, Martin R, Alcaide F. Effectiveness of an integrated real-time PCR method for detection of the Mycobacterium tuberculosis Complex in smear-negative extrapulmonary samples in an area of low tuberculosis prevalence. J Clin Microbiol $2012 ; 50: 513-515$

[15] Noussair L, Bert F, Leflon-Guibout V, Gayet N, Nicolas-Chanoine MH. Early diagnosis of extrapulmonary tuberculosis by a new procedure combining broth culture and PCR. J. Clin. Microbiol 2009; 47:1452-1457. 
Table 1. Culture-positive specimens: type and Xpert assay result

Tableau 1. Échantillons à culture positive : type et résultat du test Xpert

\begin{tabular}{|c|c|c|c|}
\hline $\begin{array}{l}\text { Day of culture- } \\
\text { enhanced PCR }\end{array}$ & Clinical specimen & $\begin{array}{l}\text { Time to } \\
\text { detection in } \\
\text { liquid culture } \\
\text { (days) }\end{array}$ & $\begin{array}{l}\text { Culture } \\
\text { enhanced- } \\
\text { Xpert assay }\end{array}$ \\
\hline \multicolumn{4}{|l|}{ Day 5} \\
\hline & Sputum & 33 & Negative \\
\hline & Sputum & 14 & Positive \\
\hline & Lymph node & 21 & Positive \\
\hline & Lymph node & 23 & Positive \\
\hline & Lymph node & 28 & Positive \\
\hline & Lymph node & 32 & Negative \\
\hline & Vertebral biopsy & 13 & Positive \\
\hline & Vertebral biopsy & 34 & Positive \\
\hline & Vertebral biopsy & 35 & Positive \\
\hline & Psoas abscess & 12 & Positive \\
\hline & Psoas abscess & 14 & Positive \\
\hline & Peritoneal fluid & 30 & Negative \\
\hline & Pleural fluid & 41 & Negative \\
\hline & Cerebral biopsy & 20 & Negative \\
\hline \multicolumn{4}{|l|}{ Day 10} \\
\hline & Sputum & 28 & Negative \\
\hline & Sputum & 43 & Negative \\
\hline & Sputum & 40 & Positive \\
\hline & Sputum & 21 & Positive \\
\hline & Bronchoalveolar lavage & 32 & Positive \\
\hline & Vertebral biopsy & 21 & Positive \\
\hline & Vertebral biopsy & 21 & Positive \\
\hline \multicolumn{4}{|l|}{ Day 15} \\
\hline & Bronchial aspirate & 30 & Positive \\
\hline & Sputum & 19 & Positive \\
\hline & Sputum & 25 & Positive \\
\hline & Lymph node & 25 & Positive \\
\hline & Lymph node & 23 & Positive \\
\hline & Lymph node & 18 & Positive \\
\hline & Lymph node & 19 & Positive \\
\hline & Pleural fluid & 19 & Positive \\
\hline & Pleural fluid & 25 & Positive \\
\hline
\end{tabular}


Table 2. Comparison of culture-enhanced PCR (Enhanced Xpert) results with culture results in respiratory and non-respiratory specimens on days 5, 10, and 15 of incubation in liquid culture

Tableau 2. Comparaison des résultats de la pré-culture/PCR avec les résultats de culture dans des échantillons respiratoires et non-respiratoires aux jours 5, 10 et 15 de l'incubation en culture liquide

\begin{tabular}{lcccc}
\hline Day 5 & \multicolumn{2}{c}{ Culture } & Total \\
& & $\mathbf{P}^{*}$ & $\mathbf{N}^{\$}$ & \\
\hline Respiratory specimens & & & \\
\hline Enhanced-Xpert & $\mathrm{P}$ & 1 & 0 & 1 \\
& $\mathrm{~N}$ & 1 & 75 & 76 \\
\hline $\begin{array}{l}\text { Non-respiratory } \\
\text { specimens }\end{array}$ & & & & \\
\hline & $\mathrm{P}$ & 8 & 0 & 8
\end{tabular}

Enhanced-Xpert

\begin{tabular}{|c|c|c|c|}
\hline $\mathrm{N}$ & 4 & 88 & 92 \\
\hline Total specimens & 14 & 163 & 177 \\
\hline \multirow{2}{*}{ Day 10} & \multicolumn{2}{|c|}{ Culture } & Total \\
\hline & $\mathbf{P}$ & $\mathbf{N}$ & \\
\hline \multicolumn{4}{|l|}{ Respiratory specimens } \\
\hline $\mathrm{P}$ & 3 & 0 & 3 \\
\hline
\end{tabular}

Enhanced-Xpert

\begin{tabular}{lllll} 
& $\mathrm{N}$ & 2 & 41 & 43 \\
\hline $\begin{array}{l}\text { Non-respiratory } \\
\text { specimens }\end{array}$ & & & & \\
\hline & $\mathrm{P}$ & 2 & 0 & 2
\end{tabular}

Enhanced-Xpert

\begin{tabular}{|c|c|c|c|}
\hline $\mathrm{N}$ & 0 & 41 & 41 \\
\hline Total specimens & 7 & 82 & 89 \\
\hline \multirow[t]{2}{*}{ Day 15} & \multicolumn{2}{|c|}{ Culture } & Total \\
\hline & $\mathbf{P}$ & $\mathbf{N}$ & \\
\hline \multicolumn{4}{|l|}{ Respiratory specimens } \\
\hline $\mathrm{P}$ & 4 & 0 & 4 \\
\hline
\end{tabular}

Enhanced-Xpert

\begin{tabular}{lcccc} 
& $\mathrm{N}$ & 0 & 38 & 38 \\
\hline $\begin{array}{l}\text { Non-respiratory } \\
\text { specimens }\end{array}$ & & & & \\
\hline & $\mathrm{P}$ & 5 & 0 & 5
\end{tabular}

Enhanced-Xpert

\begin{tabular}{lcccc} 
& $\mathrm{N}$ & 0 & 61 & 61 \\
\hline Total & & 9 & 99 & 108 \\
\hline
\end{tabular}

